\title{
Relation between Moisture Stress and Mineral Soil Tolerance in Blueberries
}

\author{
W.A. Erb ${ }^{1}$ and A.D. Draper ${ }^{2}$ \\ Fruit Laboratory, Agricultural Research Service, U.S. Department of Agriculture, Beltsville, \\ MD 20705 \\ H. J. Swartz ${ }^{3}$ \\ Department of Horticulture, University of Maryland, College Park, MD 20742 \\ Additional index words. Vaccinium ashei, Vaccinium corymbosum, Vaccinium darrowi, interspecific hybrid, fruit \\ breeding, upland soil, drought
}

\begin{abstract}
The relationship between moisture stress and mineral soil tolerance was studied by placing 10 blueberry (Vaccinium) clones in a Berryland sand soil high in organic matter (Berryland) and a Galestown sandy clay loam soil (Galestown) and subjecting them to one of two moisture regimes. The Berryland and Galestown soils represent an excellent blueberry soil and a mineral soil, respectively. A moderate degree of water stress influenced biomass partitioning in blueberries in a similar manner as stress induced by culture on mineral soil. Berryland control plants on Berryland partitioned more biomass into leaves and produced more dry matter and leaf area than plants on Galestown or those moisture stressed. Net assimilation rate and relative growth rate were not significantly different between soil or moisture treatments. The primary reason for the reduction in absolute growth rate due to soil type or moisture stress was a significantly lower leaf area duration on Galestown soil and in-moisture stressed plants. Clones differed in instantaneous transpiration, leaf conductance, and apparent photosynthesis and the ability to partition biomass into various plant parts. By selecting for increased leafiness, a high photosynthetic rate, and a more energy efficient root system, improvement in mineral soil tolerance should be possible.
\end{abstract}

Highbush blueberry (Vaccinium corymbosum L.) production is limited to acidic sandy soils high in organic matter unless certain management practices are used. These practices include modifying a mineral soil low in chemically and physically reactive organic matter with the addition of peatmoss, mulch, and irrigation. Organic matter additions and irrigation were shown by Spiers (1983) to increase growth and establishment of 'Tifblue' planted in a mineral soil low in organic matter. In a more recent report (Spiers, 1986), mulch alone was found to increase root dry weight in 'Tifblue' over incorporated peatmoss or irrigation. Korcak (1986) examined five interspecific blueberry progenies in three mineral soils and was unable to find a significant increase in plant size due to peatmoss incorporation in two of the soils during the 2 nd year of the study.

Overcoming some of the strict soil requirements of blueberries with addition of fresh organic matter and drip irrigation is expensive (Fowler et al., 1981). Development of blueberry cultivars that are vigorous and productive on unamended mineral soils would be economically more efficient. In previous studies, we found genetic variability for drought resistance (Erb et al., 1988a, 1988b), and several researchers have reported genetic variation between and among species for mineral soil tolerance (Chandler et al., 1985; Erb et al., 1990; Korcak, 1986; Korcak et al., 1982). Southern blueberry species tend to be more drought resistant and more vigorous on mineral soil than northern ones (Erb et al., 1988b; Galletta, 1975).

Knowing the relationship between drought resistance and mineral soil tolerance could assist in breeding for improved mineral soil adaptability. This study was conducted to examine

Received for publication 19 June 1992. Accepted for publication 29 July 1992. The cost of publishing this paper was defrayed in part by the payment of page charges. Under postal regulations, this paper therefore must be hereby marked advertisement solely to indicate this fact.

'Graduate Student. Presently: Assistant Professor, Dept. of Horticulture, Ohio Agr. Res. and Dev. Ctr., Wooster, OH 44691.

${ }^{2}$ Research Geneticist.

${ }^{3}$ Associate Professor.
Table 1. Species content and ploidy level $(x=12)$ of Vaccinium clones used.

\begin{tabular}{|c|c|c|}
\hline Clone & Ploidy & Species complement \\
\hline Bluecrop & $4 x$ & Vaccinium corymbosum $\mathrm{L}$. \\
\hline Tifblue & $6 x$ & V. ashei Reade \\
\hline Fla-4B & $2 x$ & $V$. darrowi Camp \\
\hline JU11 & $6 x$ & $\begin{array}{l}\text { 'Tifblue' x US41 ( } V . \text { atrococcum Heller) } \\
\text { (colchiploid) }\end{array}$ \\
\hline JU64 & $4 x$ & $V$. myrsinites Lamark $\times V$. angustifolium Aiton \\
\hline US75 & $4 x$ & Fla-4B x 'Bluecrop' \\
\hline US226 & $4 x$ & $\begin{array}{l}\text { (V. myrtilloides Michaux } \times V \text {. atrococcum) } \\
\text { (colchiploid) }\end{array}$ \\
\hline G362 & $4 x$ & V. corymbosum \\
\hline NC1767 & $4 x$ & $($ Fla-4B $\times V$. corymbosum $) \times$ US75 \\
\hline
\end{tabular}

the relationship between drought resistance and mineral soil tolerance and to learn more about the growth and partitioning of biomass in blueberries grown on a mineral soil.

\section{Materials and Methods}

Ten clones (Fla-4B, JU64, US75, NC1767, 'Bluecrop'; G362, 'Tifblue', JU11, US226, and US41) were placed in a Berryland (Typic Haplaguad) $(\mathrm{pH}=4.0,3.0 \%$ organic matter, 95\% sand, $1 \%$ silt, and $4 \%$ clay) and a Galestown (Psammentic Hapludult) $(\mathrm{pH}=4.3,1.3 \%$ organic matter, $59 \%$ sand, $17 \%$ silt, and $24 \%$ clay) soil and subjected to one of two moisture regimes in a greenhouse. The Berryland and Galestown soils represent an

Abbreviations: A, apparent net photosynthesis; Berryland, Berryland sand soil high in organic matter; CYV, canopy volume; DMP, dry-matter production; E, transpiration; $g_{\mathrm{L}}$, leaf conductance of water; Galestown, Galestown sandy clay loam soil; IC, internal leaf $\mathrm{CO}_{2}$ concentration; $\mathrm{LAD}$, leaf area duration; LAP, leaf area production; LAR, leaf area ratio; LT, leaf temperature; LW, leaf dry weight; LWR, leaf weight ratio; NAR, net assimilation rate; RGR, relative growth rate; RW, root dry weight; RWR, root dry weight ratio; SLA, specific leaf area; S : R, shoot : root ratio; SW, stem dry weight; SWR, stem weight ratio; TLA, total leaf area; WUE, water use efficiency; 25LA, 25 leaf sample area. 
Table 2. Biomass characteristics of blueberry clones grown for 18 weeks in one of two soils and for 12 of these weeks at one of two moisture levels.

\begin{tabular}{|c|c|c|c|c|c|c|c|c|c|c|c|c|}
\hline Variable & $\begin{array}{c}\text { No. } \\
\text { samples }\end{array}$ & $\begin{array}{l}\text { TLA } \\
\left(\mathrm{cm}^{2}\right) \\
\end{array}$ & $\begin{array}{l}25 \mathrm{LA} \\
\left(\mathrm{cm}^{2}\right)\end{array}$ & $\begin{array}{l}\text { LW } \\
(\mathrm{g})\end{array}$ & $\begin{array}{l}\text { SW } \\
(\mathrm{g})\end{array}$ & $\begin{array}{l}\text { RW } \\
(\mathrm{g})\end{array}$ & $\begin{array}{l}S: R \\
(g / g)\end{array}$ & $\begin{array}{l}\text { RWR } \\
(g / g)\end{array}$ & $\begin{array}{l}\text { SWR } \\
(g / g)\end{array}$ & $\begin{array}{l}\text { LWR } \\
(\mathrm{g} / \mathrm{g})\end{array}$ & $\begin{array}{c}\text { SLA } \\
\left(\mathrm{cm}^{2} \cdot \mathrm{g}^{-1}\right)\end{array}$ & $\begin{array}{c}\text { LAR } \\
\left(\mathrm{cm}^{2} \cdot \mathrm{g}^{-1}\right)\end{array}$ \\
\hline \multicolumn{13}{|l|}{ Soil } \\
\hline $\begin{array}{l}\text { Berryland } \\
\text { Galestown } \\
\text { Moisture }\end{array}$ & $\begin{array}{l}62 \\
88\end{array}$ & $\begin{array}{l}2750 a^{z} \\
1616 b\end{array}$ & $\begin{array}{l}360 \mathrm{a} \\
305 \mathrm{~b}\end{array}$ & $\begin{array}{l}23.9 \mathrm{a} \\
13.5 \mathrm{~b}\end{array}$ & $\begin{array}{r}15.7 \mathrm{a} \\
9.8 \mathrm{~b}\end{array}$ & $\begin{array}{l}9.6 \mathrm{a} \\
6.3 \mathrm{~b}\end{array}$ & $\begin{array}{l}7.1 \mathrm{a} \\
4.6 \mathrm{~b}\end{array}$ & $\begin{array}{l}0.166 \mathrm{~b} \\
0.202 \mathrm{a}\end{array}$ & $\begin{array}{l}0.332 \mathrm{a} \\
0.333 \mathrm{a}\end{array}$ & $\begin{array}{l}0.502 \mathrm{a} \\
0.466 \mathrm{~b}\end{array}$ & $\begin{array}{l}128 \mathrm{a} \\
127 \mathrm{a}\end{array}$ & $\begin{array}{l}63.5 \mathrm{a} \\
58.7 \mathrm{~b}\end{array}$ \\
\hline $\begin{array}{l}\text { Control } \\
\text { Stress } \\
\end{array}$ & $\begin{array}{l}61 \\
89 \\
\end{array}$ & $\begin{array}{l}2604 \mathrm{a} \\
1729 \mathrm{~b} \\
\end{array}$ & $\begin{array}{l}374 \mathrm{a} \\
296 \mathrm{~b}\end{array}$ & $\begin{array}{l}22.8 \mathrm{a} \\
14.4 \mathrm{~b} \\
\end{array}$ & $\begin{array}{r}15.8 \mathrm{a} \\
9.8 \mathrm{~b} \\
\end{array}$ & $\begin{array}{r}10.5 \mathrm{a} \\
5.7 \mathrm{~b} \\
\end{array}$ & $\begin{array}{l}6.3 \mathrm{a} \\
5.2 \mathrm{~b} \\
\end{array}$ & $\begin{array}{l}0.179 \mathrm{a} \\
0.193 \mathrm{a} \\
\end{array}$ & $\begin{array}{l}0.336 \mathrm{a} \\
0.329 \mathrm{a} \\
\end{array}$ & $\begin{array}{l}0.484 \mathrm{a} \\
0.479 \mathrm{a} \\
\end{array}$ & $\begin{array}{l}129 \mathrm{a} \\
126 \mathrm{a} \\
\end{array}$ & $\begin{array}{l}62.6 \mathrm{a} \\
59.4 \mathrm{a} \\
\end{array}$ \\
\hline
\end{tabular}

Table 3. Growth characteristics of blueberry clones grown for 6 weeks in one of two soils at one of two moisture levels.

\begin{tabular}{|c|c|c|c|c|c|}
\hline Variable & $\begin{array}{c}\text { DMP } \\
(\mathrm{g})\end{array}$ & $\begin{array}{l}\text { LAP } \\
\left(\mathrm{cm}^{2}\right)\end{array}$ & $\begin{array}{c}\text { NAR } \\
\left(\mathrm{g} \cdot \mathrm{m}^{-2}\right. \\
\left.\text { week }^{-1}\right)\end{array}$ & $\begin{array}{c}\text { LAD } \\
\left(\mathrm{cm}^{2} \mathrm{wk}\right)\end{array}$ & $\begin{array}{c}\text { RGR } \\
\left(\mathrm{g} \cdot \text { day }^{-1}\right)\end{array}$ \\
\hline \multicolumn{6}{|l|}{ Soil } \\
\hline $\begin{array}{l}\text { Berryland } \\
\text { Galestown } \\
\text { Moisture }\end{array}$ & $\begin{array}{l}28.8 \mathrm{a}^{\mathrm{z}} \\
17.9 \mathrm{~b}\end{array}$ & $\begin{array}{r}1062 \mathrm{a} \\
574 \mathrm{~b}\end{array}$ & $\begin{array}{l}2.86 \mathrm{a} \\
2.82 \mathrm{a}\end{array}$ & $\begin{array}{l}8.30 \mathrm{a} \\
5.56 \mathrm{~b}\end{array}$ & $\begin{array}{l}0.021 \mathrm{a} \\
0.021 \mathrm{a}\end{array}$ \\
\hline $\begin{array}{l}\text { Control } \\
\text { Stressed }\end{array}$ & $\begin{array}{l}31.5 \mathrm{a} \\
17.3 \mathrm{~b}\end{array}$ & $\begin{array}{r}1078 \mathrm{a} \\
628 \mathrm{~b} \\
\end{array}$ & $\begin{array}{l}3.10 \mathrm{a} \\
2.67 \mathrm{a} \\
\end{array}$ & $\begin{array}{l}8.24 \mathrm{a} \\
5.94 \mathrm{~b}\end{array}$ & $\begin{array}{l}0.022 \mathrm{a} \\
0.019 \mathrm{a}\end{array}$ \\
\hline
\end{tabular}

${ }^{z}$ Mean separation within columns by $\mathrm{F}$ Test, $P=0.05 ; \mathrm{n}=48$ for both variables.

excellent blueberry soil and a mineral soil, respectively. Parentage as to species content and ploidy level of the Vaccinium clones are listed in Table 1. The experiment was arranged in a completely randomized design and was run during the summer of 1985. One-year-old softwood cuttings were potted in 3.78 liters of either Berryland or Galestown soil. In most cases, 18 cuttings were potted in the Galestown soil and 17 in Berryland. The plants were grown for 2 weeks then fertilized with Peters acid special 21N-3.1P-5.8K fertilizer (W.R. Grace \& Co., Fogelsburg, Pa.) plus Fe chelate, and at the end of 6 weeks with the Peters acid special plus Miller (VHPF) (Miller Chemical \& Fertilizer Co., Baltimore) complete fertilizer at rates we used previously (Erb et al., 1988a).

After a 6-week adjustment period, canopy volumes (CYV) (height $\times$ width $\times$ breadth) of all the plants in the study were measured. The plants were placed on one of two greenhouse benches, one being the control and the other a moisture stress treatment. For each clone, seven pots each of both soil types were used as controls and nine pots of Galestown and eight pots of Berryland were placed in the stress treatment. The plants to be stressed were sorted into three classes based on their CYV (class $1=0.0014-0.011 \mathrm{~m}^{3}$, class $2=0.012-0.052 \mathrm{~m}^{3}$, and class $3=0.053-0.109 \mathrm{~m}^{3}$ ). Because of the variability in plant size, each class was not represented by all clones; some clones only occurred in one class. The level of moisture stress imposed was determined by recording the number of days re- quired for succulent growth to wilt after the soil had been saturated. For the Galestown soil, classes 1, 2, and 3 took 7, 6, and 5 days to wilt, respectively, and for the Berryland soil they took 8, 7, and 6 days, respectively. The plants were subjected to this pattern of saturation and drying for 12 weeks. During the 12 weeks of treatment the plants on both benches (control and stress) were fertilized after every other stress cycle, starting with the end of the second cycle. They were fertilized by the following schedule: first with Peters acid special, then with Peters acid special plus Fe chelate, and finally with Peters acid special plus Miller complete. The schedule was then repeated until the experiment ended. For the entire 18 weeks of the experiment the plants were fertilized seven times with Peters acid special, three times with Fe chelate, and twice with Miller complete.

At the end of the first 6 weeks of moisture stress, four plants per soil per treatment of Fla-4B, NC1767, JU64, 'Bluecrop', JU11, and US226 had their roots washed, leaf area determined and leaves, roots, and stems partitioned, dried and weighed (leaf weight $=\mathrm{LW}$; stem weight $=\mathrm{SW}$; and root weight $=\mathrm{RW})$. The total leaf area (TLA) and a 25-leaf sample area (25LA) was determined by using a LI-COR 3100 area meter (LI-COR, Lincoln, Neb). At the end of 12 weeks, the above data were collected on all the plants in the study. Dry-matter production and biomass allocation patterns of plants in this study were compared using mathematical growth analysis techniques (Gardner et al., 1985; Hunt, 1978; Patterson and Flint, 1983). Data from all the plants at the 12-week harvest were used to calculate leaf weight ratio (LWR), stem weight ratio (SWR), root weight ratio (RWR), specific leaf area (SLA), leaf area ratio (LAR) and shoot : root ratio (S : R). Data from Fla-4B, NC1767, JU64 'Bluecrop', JU11, and US266 on both the 6th and 12th week; of moisture stress were used to calculate dry-matter production (DMP), leaf area production (LAP), net assimilation rate (NAR), leaf area duration (LAD), and relative growth rate (RGR) for a 6-week interval.

A LI-COR 6000 portable photosynthesis unit was used to monitor simultaneously apparent net photosynthesis (A), transpiration $(\mathrm{E})$, leaf conductance of water $\left(\mathrm{g}_{\mathrm{L}}\right)$, leaf temperature (LT), and internal leaf $\mathrm{CO}_{2}$ concentration (IC) on control plants

Table 4. Biomass characteristics of blueberry clones grown for 12 weeks in one of two soils at one of two moisture levels.

\begin{tabular}{|c|c|c|c|c|c|c|c|}
\hline Soil & $\begin{array}{c}\text { Moisture } \\
\text { level }\end{array}$ & $\begin{array}{c}\text { No. } \\
\text { samples }\end{array}$ & $\begin{array}{l}\text { TLA } \\
\left(\mathrm{cm}^{2}\right)\end{array}$ & $\begin{array}{l}25 \mathrm{LA} \\
\left(\mathrm{cm}^{2}\right) \\
\end{array}$ & $\begin{array}{l}\text { LW } \\
(\mathrm{g}) \\
\end{array}$ & $\begin{array}{l}\text { SW } \\
(\mathrm{g})\end{array}$ & $\begin{array}{c}\text { RW } \\
(\mathrm{g})\end{array}$ \\
\hline Berryland & $\begin{array}{l}\text { Control } \\
\text { Stress }\end{array}$ & $\begin{array}{l}27 \\
35\end{array}$ & $\begin{array}{l}3285 \mathrm{a}^{\mathrm{z}} \\
2338 \mathrm{~b}\end{array}$ & $\begin{array}{l}388 \mathrm{a} \\
339 \mathrm{bc}\end{array}$ & $\begin{array}{l}29.8 \mathrm{a} \\
19.3 \mathrm{~b}\end{array}$ & $\begin{array}{l}19.7 \mathrm{a} \\
12.6 \mathrm{~b}\end{array}$ & $\begin{array}{r}13.7 \mathrm{a} \\
6.4 \mathrm{~b}\end{array}$ \\
\hline Galestown & $\begin{array}{l}\text { Control } \\
\text { Stress } \\
\end{array}$ & $\begin{array}{l}34 \\
54 \\
\end{array}$ & $\begin{array}{l}2063 \mathrm{~b} \\
1335 \mathrm{c}\end{array}$ & $\begin{array}{l}364 \mathrm{a} \\
269 \mathrm{c} \\
\end{array}$ & $\begin{array}{l}17.2 \mathrm{~b} \\
11.2 \mathrm{c} \\
\end{array}$ & $\begin{array}{r}12.6 \mathrm{~b} \\
8.0 \mathrm{c} \\
\end{array}$ & $\begin{array}{l}7.9 \mathrm{~b} \\
5.3 \mathrm{c} \\
\end{array}$ \\
\hline
\end{tabular}


Table 5. Growth characteristics of blueberry clones grown for 6 weeks in one of two soils at one of two moisture levels.

\begin{tabular}{llcccc}
\hline \hline Soil & $\begin{array}{c}\text { Moisture } \\
\text { levels }\end{array}$ & $\begin{array}{c}\text { DMP } \\
(\mathrm{g})\end{array}$ & $\begin{array}{c}\text { LAP } \\
\left(\mathrm{cm}^{2}\right)\end{array}$ & $\begin{array}{c}\text { NAR } \\
\left(\mathrm{g} \cdot \mathrm{m}^{-2} .\right. \\
\text { week }\end{array}$ & $\begin{array}{c}\text { LAD } \\
\left(\mathrm{cm}^{2} \mathrm{wk}\right)\end{array}$ \\
\hline Berryland & Control & $40.7 \mathrm{a}^{2}$ & $1324 \mathrm{a}$ & $3.32 \mathrm{a}$ & $9.82 \mathrm{a}$ \\
& Stress & $20.8 \mathrm{~b}$ & $885 \mathrm{~b}$ & $2.55 \mathrm{a}$ & $7.26 \mathrm{~b}$ \\
Galestown & Control & $22.9 \mathrm{~b}$ & $846 \mathrm{~b}$ & $2.90 \mathrm{a}$ & $6.76 \mathrm{~b}$ \\
& Stress & $13.9 \mathrm{c}$ & $399 \mathrm{c}$ & $2.78 \mathrm{a}$ & $4.78 \mathrm{c}$ \\
\hline
\end{tabular}

${ }^{2}$ Mean separation by Duncan's multiple range test, $P=0.05 ; \mathrm{n}=24$ for each treatment.

of JU64, Fla-4B, 'Bluecrop', US226, JU11, and NC1767 growing $\mathrm{i}$ both soils. Water use efficiency (WUE) was calculated as A/E. The gas-exchange of two attached leaves, fully mature and fully exposed to the sun in the upper part of the canopy, were sampled from each plant. Data were taken from two plants per clone per soil between 1000 and $1300 \mathrm{HR}$ on 12 and 13 Aug. The methods of measurement were identical with those we described earlier (Erb et al., 1991).

\section{Results and Discussion}

Biomass allocation measurements after 12 weeks of exposure to one of two soils and for six of these weeks at one of two moisture levels are not presented because they were similar to the biomass data collected at the end of the experiment. After 18 weeks in the soils, TLA, 25LA, LW, SW, RW, S : R, LWR, and LAR were all higher for Berryland- than for Galestowngrown plants (Table 2). These data indicate that Berryland-grown plants partitioned more biomass into their leaves. The Galestown-grown plants partitioned more biomass into their roots; RWR was significantly higher. The higher 25LA for the Berryland-grown plants indicates that their leaves were larger. The similarity in SLA among the soils indicates that the ratio of leaf area to leaf dry weight remained the same. The higher LAR for Berryland-grown plants reflects greater leafiness for these plants (increased photosynthetic capacity). Moisture treatment differences after 12 weeks of exposure indicate that a moderate drought stress affects blueberries in a manner similar to growth in a mineral soil (Table 2). The major differences between moisture stress and stress on a mineral soil were that the RWR, LWR, and LAR values for the moisture treatments, unlike those for the soils, were not significantly different.

Absolute growth rate (DMP and LAP) was lower for Galestown than for Berryland-grown plants over a 6-week interval (Table 3). However, there was no significant difference in mean NAR and mean RGR, indicating that the leaf area of Galestowngrown plants was just as efficient at producing biomass as Berryland-grown plants. The difference in absolute growth rate was due to the mean LAD being higher for the Berryland-grown plants. The higher LAD indicates that, over the 6-week interval, Berryland-grown plants had more leaf area, which means more light interception and a higher total plant photosynthetic rate. Absolute growth rate was reduced in the moisture-stressed plants, the primary reason being a reduction in LAD over the 6-week interval.

The soil $\times$ moisture treatment interactions provided more evidence for the similarity of growth under drought stress and on a mineral (Galestown) soil (Tables 4 and 5). The effects of Berryland $\times$ moisture stress and Galestown $\times$ control only differed in 25LA, indicating that leaf area was reduced more by moisture stress than growth on a mineral soil (Table 4). This result suggests that the water stress was probably the more severe treatment. There were no significant differences for the treatment interactions involving mean S : R, RWR, SWR, LWR, SLA, LAR, RGR, and NAR. However, there was a trend toward decreased NAR when plants were grown in the Galestown soil or exposed to a moisture stress (Table 5). Data for moisture treatment of clones were not analyzed because the three classes the plants were originally placed in, were significantly different in CYV production.

Instantaneous gas exchange measurements indicate that Galestown-grown plants were significantly higher in E, A, and WUE (Table 6). There were no significant differences among soil treatments in IC, LT, and gL. The higher WUE was due to the higher $\mathrm{A}$ in Galestown-grown plants. Because moisture was not lacking for any of the plants measured, a high WUE is considered unimportant (Jones, 1983). However, a high WUE and a lower stomata1 conductance are important with an irrigated mineral soil, because both US75 and JU11 produced a large canopy volume and had a high WUE and a low stomata1 conductance when grown to maturity on a mineral soil that was unamended with organic matter (Erb et al., 1991).

In all the clones, except 'Bluecrop' and JU11, percentage of root biomass tended to be higher for Galestown-grown plants, while percentage of leaf biomass tended to be higher for Berryland-grown plants (Table 7). The opposite significant difference in 'Bluecrop' was probably due to some of the Berryland plants becoming pot-bound, which slowed shoot growth. Some clones partitioned $>50 \%$ of their biomass into leaves. Significant clonal differences for percent roots and percent leaves indicate that selection for changes in biomass partitioning in blueberry interspecific populations is possible. Selecting for an increase in percent leaves also may increase tolerance to mineral soil.

The growth of Fla-4B, US226, and 'Bluecrop' was the least affected by the soil treatment, as indicated by the lack of significant difference between DMP and LAD due to soil. The species that constitute Fla-4B ( $V$. darrowi) and US226 (V. myrtilloides $\times V$. atrococcum) are reported (Galletta, 1975) to be adapted to mineral soils; so, one might expect them to perform well on a mineral soil. However, the performance of 'Bluecrop' was unexpected, because $V$. corymbosum is not known to be adapted to mineral soils. The high DMP for Galestown-grown 'Bluecrop' plants may explain why 'Bluecrop' is a broadly adapted highbush cultivar; it is productive in New Jersey, Michigan, Arkansas, and the Pacific Northwest. The Berryland- and Galestown-grown plants of JU11 and JU64, which are composed of two mineral soil adapted species and NC1767, composed of one

Table 6. Instantaneous gas exchange measurements for blueberry clones growing in one of two soils.

\begin{tabular}{|c|c|c|c|c|c|c|}
\hline Soil & $\begin{array}{c}\mathrm{E} \\
\left(\mathrm{mmol} \cdot \mathrm{m}^{-2} \cdot \mathrm{s}^{-1}\right)\end{array}$ & $\begin{array}{c}\mathrm{IC} \\
(\mathrm{ppm})\end{array}$ & $\begin{array}{l}\text { LT } \\
\left({ }^{\circ} \mathrm{C}\right)\end{array}$ & $\underset{\left(\mathrm{mol} \cdot \mathrm{m}^{-2} \cdot \mathrm{s}^{-1}\right)}{\mathrm{g}_{\mathrm{L}}}$ & $\begin{array}{c}\mathrm{A} \\
\left(\mu \mathrm{mol} \cdot \mathrm{m}^{-2} \cdot \mathrm{s}^{-1}\right)\end{array}$ & $\begin{array}{l}\text { WUE } \\
\text { (A/E) }\end{array}$ \\
\hline Galestown & $4.64 \mathrm{a}^{\mathrm{z}}$ & $248 \mathrm{a}$ & $32.7 \mathrm{a}$ & $0.25 \mathrm{a}$ & $6.57 \mathrm{a}$ & $1.45 \mathrm{a}$ \\
\hline Berryland & $4.26 \mathrm{~b}$ & 249 a & $32.5 \mathrm{a}$ & $0.23 \mathrm{a}$ & $5.30 \mathrm{~b}$ & $1.28 \mathrm{~b}$ \\
\hline
\end{tabular}

${ }^{2}$ Mean separation within columns by $\mathrm{F}$ test, $P=0.05 ; \mathrm{n}=56$ for both soils. 
Table 7. Percentage of biomass partitioned into roots and leaves by blueberry clones grown for 18 weeks in one of two soils.

\begin{tabular}{llccc}
\hline \hline & & & \multicolumn{2}{c}{ Biomass } \\
\cline { 4 - 5 } Clone & Soil & $\begin{array}{c}\text { No. } \\
\text { samples }\end{array}$ & $\begin{array}{c}\text { Roots } \\
(\%)\end{array}$ & $\begin{array}{c}\text { Leaves } \\
(\%)\end{array}$ \\
\hline Bluecrop & Berryland & 3 & $31.7 \mathrm{a}^{\mathrm{z}}$ & $37.4 \mathrm{ef}$ \\
& Galestown & 3 & $16.0 \mathrm{cdef}$ & $47.2 \mathrm{cde}$ \\
Tifblue & Berryland & 3 & $24.1 \mathrm{~b}$ & $46.7 \mathrm{cde}$ \\
& Galestown & 3 & $24.6 \mathrm{~b}$ & $45.5 \mathrm{~cd}$ \\
G362 & Berryland & 2 & $14.4 \mathrm{cdefgh}$ & $42.7 \mathrm{def}$ \\
& Galestown & 2 & $20.3 \mathrm{bc}$ & $36.4 \mathrm{f}$ \\
Fla-4B & Berryland & 3 & $4.6 \mathrm{i}$ & $62.3 \mathrm{a}$ \\
& Galestown & 3 & $10.3 \mathrm{fghi}$ & $55.5 \mathrm{abc}$ \\
JU11 & Berryland & 3 & $21.3 \mathrm{bc}$ & $49.1 \mathrm{bcd}$ \\
& Galestown & 3 & $19.9 \mathrm{bcd}$ & $49.0 \mathrm{bcd}$ \\
JU64 & Berryland & 3 & $9.7 \mathrm{ghi}$ & $57.5 \mathrm{ab}$ \\
& Galestown & 3 & $12.5 \mathrm{efgh}$ & $53.8 \mathrm{abc}$ \\
NC1767 & Berryland & 3 & $17.9 \mathrm{bcde}$ & $50.2 \mathrm{bcd}$ \\
& Galestown & 3 & $19.4 \mathrm{bcd}$ & $48.6 \mathrm{bcd}$ \\
US41 & Berryland & 3 & $19.5 \mathrm{bcd}$ & $50.0 \mathrm{bcd}$ \\
& Galestown & 3 & $20.2 \mathrm{bc}$ & $45.0 \mathrm{def}$ \\
US226 & Berryland & 2 & $15.4 \mathrm{cdefg}$ & $47.0 \mathrm{cde}$ \\
& Galestown & 3 & $19.2 \mathrm{bcd}$ & $43.5 \mathrm{def}$ \\
US75 & Berryland & 2 & $8.6 \mathrm{hi}$ & $55.4 \mathrm{abc}$ \\
& Galestown & 2 & $14.0 \mathrm{defgh}$ & $51.3 \mathrm{bcd}$ \\
\hline
\end{tabular}

${ }^{z}$ Mean separation by Duncan's multiple range test, $P=0.05$.

Table 8. Comparison of blueberry clone growth characteristics after 6 weeks in one of two soils.

\begin{tabular}{lllr}
\hline \hline Clone & \multicolumn{1}{c}{ Soil } & \multicolumn{1}{c}{ DMPz } & LAD \\
\hline Bluecrop & Berryland & $40.62 \mathrm{bc}^{\mathrm{z}}$ & $10.28 \mathrm{bc}$ \\
& Galestown & $31.18 \mathrm{~cd}$ & $7.11 \mathrm{~cd}$ \\
Fla-4B & Berryland & $20.56 \mathrm{de}$ & $6.71 \mathrm{~cd}$ \\
& Galestown & $19.64 \mathrm{de}$ & $6.84 \mathrm{~cd}$ \\
JU11 & Berryland & $63.45 \mathrm{a}$ & $6.52 \mathrm{~cd}$ \\
& Galestown & $25.71 \mathrm{cde}$ & $6.51 \mathrm{~d}$ \\
JU64 & Berryland & $32.94 \mathrm{~cd}$ & $11.15 \mathrm{~b}$ \\
& Galestown & $13.22 \mathrm{e}$ & $5.19 \mathrm{~d}$ \\
NC1767 & Berryland & $59.61 \mathrm{a}$ & $16.00 \mathrm{a}$ \\
& Galestown & $30.33 \mathrm{~cd}$ & $10.41 \mathrm{bc}$ \\
US226 & Berryland & $23.59 \mathrm{de}$ & $8.39 \mathrm{~cd}$ \\
& Galestown & $17.30 \mathrm{e}$ & $4.84 \mathrm{~d}$ \\
\hline zMean
\end{tabular}

${ }^{2}$ Mean separation by Duncan's multiple range test, $P=0.05 ; \mathrm{n}=4$ for each clone.

mineral soil adapted species, were significantly different in DMP. However, in a 4-year field planting on a Galestown soil, JU11 and US75 (which is similar in percentage to NC1767) and progeny from crosses with JU11, JU64, and US75 were more vigorous than G362 ( V. corymbosum) and US226 (Chandler et al., 1985; Erb et al., 1990). The proven performance of JU11 and JU64 on a mineral soil in the field and the high DMP of Galestown-grown 'Bluecrop' plants in this greenhouse study indicate that evaluation of germplasm by different methods in more than one environment is helpful when breeding for a complex trait such as mineral soil tolerance.

The instantaneous gas exchange measurements (Table 9) indicate that the lack of difference in DMP between 'Bluecrop' and Fla-4B plants on the two soils can be partially explained by a higher $\mathrm{A}$ in the Galestown-grown plants. Conversely, the Galestown-grown plants of JU11, JU64, and NC1767 had significantly lower DMP than the corresponding Berryland-grown plants, and there was no difference in A between soils. For all the clones tested, the trend was for $\mathrm{E}$ and $\mathrm{A}$ to be higher in the Galestown-grown plants. There was no difference due to soil treatments for $\mathrm{g}_{\mathrm{L}}$ and WUE in any clones, except $\mathrm{NC} 1767$ and 'Bluecrop'. The Galestown-grown clones of NC1767 had a higher $\mathrm{g}_{\mathrm{L}}$ and the Galestown 'Bluecrop' clones had a higher WUE. How a blueberry plant partitions its biomass and its net photosynthetic rate appear to be important components of mineral soil tolerance.

The reason for similarities in blueberry responses to water stress and growth on a mineral soil may be due to the lack of root hairs on a blueberry root which gives a plant poor root-soil contact similar to what occurs in dry soil. In a moisture deficit situation the unsuberized roots of a plant shrink, reducing root soil contact. Because blueberries are devoid of root hairs, they have a lower root surface area for water and nutrient absorption and should produce a less vigorous plant on an unamended mineral soil. In soil containing active organic matter, such as Berryland, the organic matter probably buffers the environment around the root system, allowing more partitioning of biomass into shoot growth and increasing LAD, which improves a plant's photosynthetic capacity. In a Galestown or a mineral soil low in active organic matter, more biomass is partitioned into roots, thus producing a lower LAD and creating a larger drain because the ratio of photosynthetic tissue to respiratory tissue decreases.

Some southern blueberry species have evolved under the pressure of drought and stress on a mineral soil ( $V$. darrowi, $V$. ashei, V. myrsinites, and V. elliotti) (Galletta, 1975; Lyrene and Sherman, 1980). Vaccinium darrowi appears to deal with stress on a mineral soil and water deficits through leaf mechanisms [low stomata1 conductance (Moon et al., 1987a) and heat tolerance (Moon et al., 1987b)], so that LAD will remain high. However, leaf mechanisms are not the only means for tolerating stress on a mineral soil. The drought-susceptible northern species V. vacillans Torrey and V. mytilloides and clones US226 and US41 (Erb et al., 1988b) probably possess root mechanisms that aid in tolerating mineral soil conditions because the species listed and the species constitution of US226 and US41 are all considered to be adapted to mineral soils (Galletta, 1975). The southern species $V$. ashei must also possess beneficial root mechanisms because when highbush scions were grafted onto rabbiteye roots, they grew on soils where ungrafted highbush plants had previously failed (Galletta and Fish, 1971).

The root physiology of rabbiteye and highbush blueberries differ. Root respiration (Korcak, 1983), root cation exchange capacity (Korcak et al., 1982), and reaction to Phytophthora cinnamomi Rands (Erb, 1983; Milholland, 1975; Milholland and Galletta, 1967) differ between rabbiteye and highbush. Vaccinium ashei roots have lower root respiration rates, accumulate less divalent cations, attracted fewer zoospores of $P$. cinnamomi and had less severe disease symptoms than $V$. corymbosum plants, all of which indicates the root system also needs to be considered in a breeding program for mineral soil adaptability. Combining the leaf and root mechanisms of southern species with the root mechanisms of the northern species would produce the best plant for a broad range of soil and climatic conditions.

The data on clones indicate the genetic variability that exists in Vaccinium for biomass partitioning and accumulation and physiological variables. Interspecific hybrids have given breeders new gene combinations; through recurrent selection and recombination, individuals that are more vigorous and productive on unamended mineral soils likely will be found (Chandler et al., 1985; Erb et al., 1990; Erb et al., 1991). Combining a high 
Table 9. Comparison of blueberry clone instantaneous gas exchange measurements monitored while growing in one of two soils.

\begin{tabular}{|c|c|c|c|c|c|}
\hline Clone & Soil & $\begin{array}{c}\mathrm{E} \\
\left(\mathrm{mmol} \cdot \mathrm{m}^{-2} \cdot \mathrm{s}^{-1}\right)\end{array}$ & $\begin{array}{c}\mathrm{g}_{\mathrm{L}} \\
\left(\mathrm{mol} \cdot \mathrm{m}^{-2} \cdot \mathrm{s}^{-1}\right)\end{array}$ & $\begin{array}{c}\mathrm{A} \\
\left(\mu \mathrm{mol} \cdot \mathrm{m}^{-2} \cdot \mathrm{s}^{-1}\right)\end{array}$ & $\begin{array}{l}\text { WUE } \\
\text { (A/E) }\end{array}$ \\
\hline Bluecrop & $\begin{array}{l}\text { Berryland } \\
\text { Galestown }\end{array}$ & $\begin{array}{l}4.73 \mathrm{bcde}^{\mathrm{z}} \\
4.23 \mathrm{cde}\end{array}$ & $\begin{array}{l}0.256 \mathrm{bcd} \\
0.208 \mathrm{~cd}\end{array}$ & $6.01 \mathrm{bc}$ & $\begin{array}{l}1.29 \mathrm{~cd} \\
1.95 \mathrm{a}\end{array}$ \\
\hline Fla-4B & Berryland & $2.39 \mathrm{f}$ & 0.102 e & $2.29 \mathrm{f}$ & $1.10 \mathrm{~cd}$ \\
\hline JU11 & $\begin{array}{l}\text { Galestown } \\
\text { Berryland }\end{array}$ & $\begin{array}{l}4.00 \mathrm{de} \\
4.84 \text { bcde }\end{array}$ & $\begin{array}{l}0.182 \mathrm{de} \\
0.241 \mathrm{bcd}\end{array}$ & $\begin{array}{l}3.91 \mathrm{e} \\
5.83 \mathrm{bcd}\end{array}$ & $\begin{array}{l}1.02 \mathrm{~d} \\
1.24 \mathrm{~cd}\end{array}$ \\
\hline & Galestown & 4.83 bcde & $0.255 \mathrm{bcd}$ & $6.99 \mathrm{ab}$ & $1.45 \mathrm{bc}$ \\
\hline JU64 & Berryland & $3.92 \mathrm{e}$ & 0.201 cde & $4.58 \mathrm{de}$ & $1.21 \mathrm{~cd}$ \\
\hline NC1767 & Galestown & $4.68 \mathrm{cde}$ & 0.181 de & $4.68 \mathrm{cde}$ & $1.29 \mathrm{~cd}$ \\
\hline & $\begin{array}{l}\text { Berryland } \\
\text { Galestown }\end{array}$ & $\begin{array}{l}5.02 \mathrm{bcd} \\
6.23 \mathrm{a}\end{array}$ & $\begin{array}{l}0.294 \mathrm{bc} \\
0.398 \mathrm{a}\end{array}$ & $\begin{array}{l}6.56 \mathrm{ab} \\
7.84 \mathrm{a}\end{array}$ & $\begin{array}{l}1.32 \mathrm{~cd} \\
1.26 \mathrm{~cd}\end{array}$ \\
\hline US226 & $\begin{array}{l}\text { Berryland } \\
\text { Galestown }\end{array}$ & $\begin{array}{l}5.06 \mathrm{bc} \\
5.33 \mathrm{ab}\end{array}$ & $\begin{array}{l}0.324 \mathrm{ab} \\
0.326 \mathrm{ab}\end{array}$ & $\begin{array}{l}6.71 \mathrm{ab} \\
7.63 \mathrm{a}\end{array}$ & $\begin{array}{l}1.33 \mathrm{~cd} \\
1.43 \mathrm{bc}\end{array}$ \\
\hline
\end{tabular}

${ }^{2}$ Mean separation by Duncan's multiple range test, $P=0.05 ; \mathrm{n}=8$ for each clone.

photosynthetic rate, the ability to partition more biomass into leaf area, and a more energy efficient root system likely will produce a plant that will be vigorous over a broad range of soil conditions. US75 seems to possess some of these characteristics. Moon et al. (1987b) showed that US75 had a higher net photosynthetic rate than either of its parents. In our study, US75 partitioned about as much biomass into its leaves as Fla-4B, and US75 was a dominant clone in producing CYV when grown in a field of Galestown soil (Erb et al., 1990). Currently, the only reported deficiency of US75 is its low fruit yield (Erb et al., 1990).

\section{Literature Cited}

Chandler, C.K., A.D. Draper, G.J. Galletta, and J.C. Bouwkamp. 1985. Combining ability of blueberry interspecific hybrids for growth on upland soil. HortScience 20:257-258.

Erb, W.A. 1983. Analysis of zoospore attraction of Phytophthora cinnamomi Rands to blueberry roots. MS Thesis, Univ. of Arkansas, Fayetteville.

Erb, W.A., A.D. Draper, G.J. Galletta, and H.J Swartz. 1990. Combining ability for plant fruit traits of interspecific blueberry progenies on mineral soil. J. Amer. Soc. Hort. Sci. 115:1025-1028.

Erb. W.A., A.D. Draper, and H.J. Swartz. 1988a. Methods of screening blueberry seedling populations for drought resistance. HortScience 23:312-314.

Erb, W.A., A.D. Draper, and H.J. Swartz. 1988b. Screening interspecific blueberry seedling populations for drought resistance. J. Amer. Soc. Hort. Sci. 113:599-604.

Erb, W.A., A.D. Draper, and H.J. Swartz. 1991. Combining ability for canopy growth and gas exchange of interspecific blueberries under moderate water deficit. J. Amer. Soc. Hort. Sci. 116:569573.

Fowler, S.R., W.L. Bateman, and J.M. Spiers. 1981. Costs and returns for small-acreage blueberry production in the Mid-Gulf region. Mississippi Agr. and For. Expt. Sta. Res. Rpt. 6(12) Mississippi State Univ.

Galletta, G.J. 1975. Blueberries and cranberries, p. 154-196. In: J. Janick and J.N. Moore (eds.). Advances in fruit breeding. Purdue Univ. Press, West Lafayette, Ind.

Galletta, G.J. and A.S. Fish, Jr. 1971. Interspecific blueberry grafting, a way to extend Vaccinium culture to different soils. J. Amer. Soc. Hort. Sci. 96:294-298.

Gardner, F.P., R.B. Pearce, and R.L. Mitchell. 1985. Physiology of' crop plants. The Iowa State Univ. Press, Ames.

Hunt, R. 1978. Plant growth analysis. Edward Arnold, London.

Jones, H.G. 1983. Plants and microclimate: A quantitative approach to environmental plant physiology. Cambridge Univ. Press, New York.

Korcak, R.F. 1983. Root respiration and soil aeration status of blueberries (Vaccinium sp.). J. Plant Nutr. 6:283-289.

Korcak, R.F. 1986. Adaptability of blueberry species to various soil types: I. Growth and initial fruiting. J. Amer. Soc. Hort. Sci. 111:816821.

Korcak, R.F., G.J. Galletta, and A.D. Draper. 1982. Response of blueberry seedlings to a range of soil types. J. Amer. Soc. Hort. Sci. 107:1153-1160.

Lyrene, P.M. and W.B. Sherman. 1980. Horticultural characteristics of native Vaccinium darrowi, V. elliotti, V. fuscatum, and V. myrsinites in Alachua County, Florida. J. Amer. Soc. Hort. 105:393396.

Milholland, R.D. 1975. Pathogenicity and histopathology of Phytophthora cinnamomi on highbush and rabbiteye blueberry. Phytopathology 65:789-793.

Milholland, R.D. and G.J. Galletta. 1967. Relative susceptibility of blueberry cultivars to Phytophthora cinnamomi. Plant Dis. Rptr. 51:998-1001.

Moon, J.W., Jr., J.A. Flore, and J.F. Hancock, Jr. 1987. A comparison of carbon and water vapor gas exchange characteristics between a diploid and highbush blueberry. J. Amer. Soc. Hort, Sci. 112:134138.

Moon, J.W., Jr., J.F. Hancock, Jr., A.D. Draper, and J.A. Flore. 1987. Genotypic differences in the effect of temperature on $\mathrm{CO}$, assimilation and water use efficiency in blueberry. J. Amer. Soc. Hort. Sci. 112:170-173

Patterson, D.T. and E.P. Flint. 1983. Comparative water relations, photosynthesis, and growth of soybean (Glycine max) and seven associated weeds. Weed Sci. 31:318-323.

Spiers, J.M. 1983. Irrigation and peatmoss for the establishment of rabbiteye blueberries. HortScience 18:936-937.

Spiers, J.M. 1986. Root distribution of 'Tifblue' rabbiteye blueberry as influenced by irrigation, incorporated peatmoss, and mulch. J. Amer. Soc. Hort. Sci. 111:877-880. 